\title{
Particle size traces modern Saharan dust transport and deposition across the equatorial North Atlantic
}

\author{
Michèlle van der Does ${ }^{1}$, Laura F. Korte ${ }^{1}$, Chris I. Munday ${ }^{1}$, Geert-Jan A. Brummer ${ }^{1,2}$, and Jan-Berend W. Stuut ${ }^{1,3}$ \\ ${ }^{1}$ NIOZ, Royal Netherlands Institute for Sea Research, Department of Ocean Systems, and Utrecht University, \\ Texel, the Netherlands \\ ${ }^{2}$ Faculty of Earth and Life Sciences, Vrije Universiteit Amsterdam, Amsterdam, the Netherlands \\ ${ }^{3}$ MARUM, Center for Marine Environmental Sciences, University of Bremen, Bremen, Germany \\ Correspondence to: Michèlle van der Does (mdoes@nioz.nl)
}

Received: 22 April 2016 - Published in Atmos. Chem. Phys. Discuss.: 2 May 2016

Revised: 13 October 2016 - Accepted: 18 October 2016 - Published: 4 November 2016

\begin{abstract}
Mineral dust has a large impact on regional and global climate, depending on its particle size. Especially in the Atlantic Ocean downwind of the Sahara, the largest dust source on earth, the effects can be substantial but are poorly understood. This study focuses on seasonal and spatial variations in particle size of Saharan dust deposition across the Atlantic Ocean, using an array of submarine sediment traps moored along a transect at $12^{\circ} \mathrm{N}$. We show that the particle size decreases downwind with increased distance from the Saharan source, due to higher gravitational settling velocities of coarse particles in the atmosphere. Modal grain sizes vary between 4 and $32 \mu \mathrm{m}$ throughout the different seasons and at five locations along the transect. This is much coarser than previously suggested and incorporated into climate models. In addition, seasonal changes are prominent, with coarser dust in summer and finer dust in winter and spring. Such seasonal changes are caused by transport at higher altitudes and at greater wind velocities during summer than in winter. Also, the latitudinal migration of the dust cloud, associated with the Intertropical Convergence Zone, causes seasonal differences in deposition as the summer dust cloud is located more to the north and more directly above the sampled transect. Furthermore, increased precipitation and more frequent dust storms in summer coincide with coarser dust deposition. Our findings contribute to understanding Saharan dust transport and deposition relevant for the interpretation of sedimentary records for climate reconstructions, as well as for global and regional models for improved prediction of future climate.
\end{abstract}

\section{Introduction}

Millions of tons of mineral dust are transported from the African continent towards the Atlantic Ocean every year, with several direct and indirect effects on global climate. CALIPSO (Cloud-Aerosol Lidar and Infrared Pathfinder Satellite Observation) lidar measurements between 2007 and 2013 show that, annually, $182 \mathrm{Tg}$ of African dust leaves the African continent towards the Atlantic Ocean, $132 \mathrm{Tg}$ reaches $35^{\circ} \mathrm{W}$, and $43 \mathrm{Tg}$ reaches as far west as $75^{\circ} \mathrm{W}$ (Yu et al., 2015). Approximately $140 \mathrm{Tg}$ is deposited in the Atlantic Ocean between 15 and $75^{\circ} \mathrm{W}$ and $10^{\circ} \mathrm{S}$ and $30^{\circ} \mathrm{N}$. Atmospheric mineral dust affects the atmosphere's radiation budget by scattering and absorbing incoming and reflected solar radiation, and changes cloud properties by acting as cloud condensation nuclei (Goudie and Middleton, 2001; Highwood and Ryder, 2014; Shao et al., 2011; Wilcox et al., 2010). Climatic effects are largely determined by particle characteristics, including particle size, particle shape, chemical and mineralogical composition, and cloud cover and the albedo of the underlying surface (Claquin et al., 2003; Goudie and Middleton, 2001, 2006; Highwood and Ryder, 2014; Otto et al., 2007; Shao et al., 2011; Sokolik and Toon, 1999). Large particles in the lower atmosphere may have a warming effect on earth's climate by absorbing reflected (longwave) radiation (Mahowald et al., 2014; Otto et al., 2007). By contrast, small particles in the higher atmosphere may have a cooling effect, by reflecting incoming solar (shortwave) radiation (Claquin et al., 2003; Mahowald et al., 2014). Moreover, dust deposition enhances ocean carbon 
Table 1. Locations and depths of the sampling stations M1-M5. BSL: below sea level.

\begin{tabular}{lrrrrrr}
\hline Station & $\begin{array}{r}\text { Latitude } \\
\left({ }^{\circ} \mathrm{N}\right)\end{array}$ & $\begin{array}{r}\text { Longitude } \\
\left({ }^{\circ} \mathrm{W}\right)\end{array}$ & $\begin{array}{c}\text { Trap depths } \\
(\mathrm{m} \text { b.s.l })\end{array}$ & $\begin{array}{c}\text { Bottom } \\
\text { depth }(\mathrm{m} \text { b.s.l) }\end{array}$ & $\begin{array}{c}\text { Distance to } \\
\text { African coast }(\mathrm{km})\end{array}$ \\
\hline M1 & 12.00 & 23.00 & 1150 & & 5000 & 700 \\
M2 & 13.81 & 37.82 & 1235 & 3490 & 4790 & 2300 \\
M3 & 12.39 & 38.63 & & 3540 & 4640 & 2400 \\
M4 & 12.06 & 49.19 & 1130 & 3370 & 4670 & 3500 \\
M5 & 12.02 & 57.04 & & 3520 & 4400 & 4400 \\
\hline
\end{tabular}

cycling by delivering nutrients that stimulate phytoplankton growth (Martin and Fitzwater, 1988; Shao et al., 2011). In turn, this leads to not only increased export fluxes but also faster transport of organic carbon to the deep ocean, as dust particles act as mineral ballast, depending on particle size, shape, and mineral density (Armstrong et al., 2002; Bressac et al., 2014; Fischer et al., 2007; Fischer and Karakas, 2009; Klaas and Archer, 2002). Both have the potential to reduce atmospheric $p \mathrm{CO}_{2}$ levels (Klaas and Archer, 2002).

The distance over which mineral dust is transported depends on the transporting winds and particle characteristics, including size, shape, and density, which determine settling velocities. Rounded quartz and feldspar particles have a greater settling velocity than platy clay minerals and are therefore deposited closer to the source (Glaccum and Prospero, 1980; Goudie and Middleton, 2006; Mahowald et al., 2014; Stuut et al., 2005). Saharan dust is transported with the trade winds year-round, from the northwestern Sahara to the eastern Atlantic Ocean. During winter, the Harmattan trade winds prevail, transporting dust from the central Sahara (Glaccum and Prospero, 1980; Stuut et al., 2005) at altitudes between 0 and $3 \mathrm{~km}$ (Tsamalis et al., 2013). In summer, when the larger land-sea temperature contrast results in large convective cells over the African continent, dust is emitted from the Sahara and Sahel. During transport towards the Atlantic Ocean, cool marine air blows in the opposite direction and lifts the warm, dusty air high up in the atmosphere. This Saharan Air Layer (SAL) is confined between two inversion layers, at 1 and $5 \mathrm{~km}$ height (Adams et al., 2012; Carlson and Prospero, 1972; Kanitz et al., 2014; Prospero and Carlson, 1972; Tsamalis et al., 2013). Due to the latitudinal movement of the ITCZ (Intertropical Convergence Zone), the dust cloud over the Atlantic Ocean also migrates seasonally (Nicholson, 2000), shifting northward $\left(10-20^{\circ} \mathrm{N}\right)$ in summer and southward $\left(0-10^{\circ} \mathrm{N}\right)$ in winter (Adams et al., 2012; Holz et al., 2004; Moulin et al., 1997; Yu et al., 2015).

The particle size of entrained and transported mineral dust depends on source conditions such as surface roughness, wind velocity, and erosion threshold and soil characteristics such as particle size, shape, and density, as well as soil moisture (d'Almeida and Schütz, 1983; Marticorena, 2014). After entrainment, the particle-size distributions are further modified by size-selective processes during transport and deposi- tion (Grini and Zender, 2004). Owing to gravitational settling, dust particle size decreases with increasing distance from the source (Holz et al., 2004; Mahowald et al., 2014; Sarnthein et al., 1981; Schütz, 1980) and generally do not exceed $20 \mu \mathrm{m}$ when transported over long distances (Gillette, 1979; Tsoar and Pye, 1987). On the Cabo Verde islands close to the Saharan source, Glaccum and Prospero (1980) found individual quartz and mica particles of up to 90 and $350 \mu \mathrm{m}$, respectively. However, various studies have also reported giant $(>62.5 \mu \mathrm{m})$ mineral dust particles at much greater distances $(>10000 \mathrm{~km})$ from their source (Betzer et al., 1988; Goudie and Middleton, 2006; Mahowald et al., 2014; Middleton et al., 2001). Climate models usually do not account for such coarse particles, and generally overestimate the fine fraction (Grini and Zender, 2004; Kok, 2011). This not only results in an underestimation of the dust flux to the oceans and in turn the fertilizing effect of the transported nutrients but also produces errors in the sign and magnitude of radiative forcing by dust and the formation of cloud condensation nuclei. This affects weather forecasts and climate predictions, especially in dusty regions (Kok, 2011).

Due to their vastness, dust over the oceans has remained poorly studied, although specific information is required for predicting future climate and past climate reconstructions (IPCC, 2013). For the present study, we focused on a transect across the Atlantic Ocean, located directly underneath the Saharan dust cloud at $12^{\circ} \mathrm{N}$ (Yu et al., 2015). We used time series from submarine sediment traps moored at five locations along this transect, sampling synchronously over successive intervals of 16 days. Here we present the first-year results on seasonal variability over the full particle-size range, analyzing source-to-sink variation of particle size in relation to large-scale atmospheric processes. Atmospheric Saharan dust has been collected at daily resolution at Barbados for more than 50 years (Prospero and Carlson, 1970; Prospero and Nees, 1977, 1986; Prospero et al., 1981; Prospero and Lamb, 2003). Although this is the longest dust record sampled to date, it is at a single and distal location relative to the Saharan source. Croot et al. (2004) sampled Saharan dust $<1 \mu \mathrm{m}$ in fall 2002 from the atmosphere along a transect across the Atlantic Ocean, while Stuut et al. (2005) also considered larger particles by shipboard sampling in winter 1998. Also, Skonieczny et al. (2013) observed tempo- 

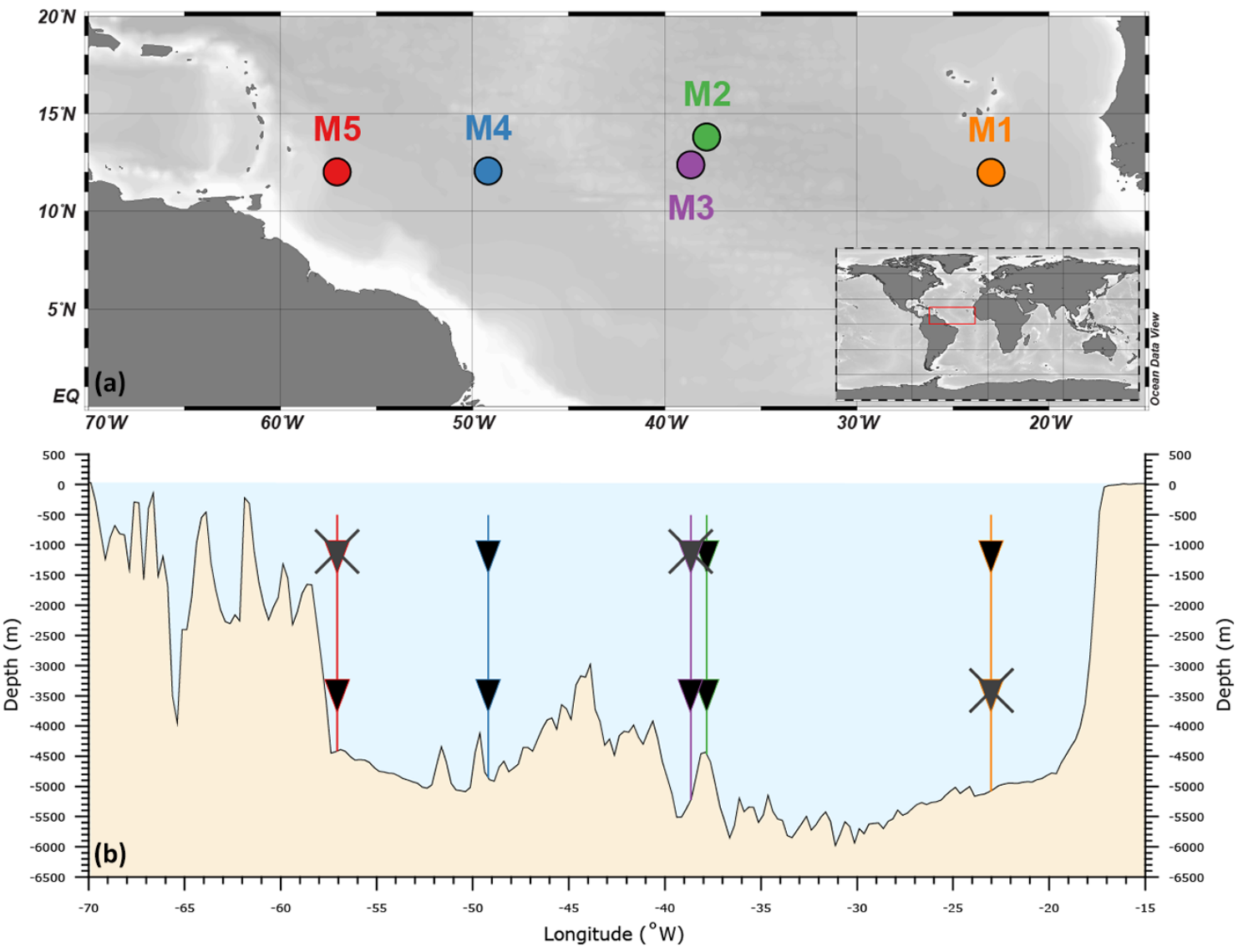

Figure 1. (a) Map with sampling stations M1-M5 in the Atlantic Ocean at $12^{\circ} \mathrm{N}$. (b) Bathymetry along $12^{\circ} \mathrm{N}$ (from http://www.gebco.net) with sediment traps at $1200 \mathrm{~m}$ and $3500 \mathrm{~m}$ b.s.l. Crossed-out sediment traps could not be recovered.

ral changes in dust outbreaks and particle characteristics like grain size and chemistry, at a single proximal location on the western African coast. They found higher fluxes during winter, as opposed to coarser particles during summer, and attribute this to the seasonally different transporting dust layers. Similar higher fluxes of coarser-grained lithogenic particles in summer were observed by Ratmeyer et al. (1999a, b), using a submarine sediment trap moored at a very proximal location just off NW Africa. Friese et al. (2016) relate seasonal changes of dust particle size in sediment traps to regional meteorological variability such as precipitation, tradewind speed, and dust-storm events. In deep-sea sediments deposited offshore northwestern Africa, Holz et al. (2004, 2007), Mulitza et al. (2008), and Zühlsdorff et al. (2007) found links between dust deposition and variability in transport mechanisms, and generally, more dust deposition in dry glacial periods than in humid interglacials, throughout the Late Quaternary.

\section{Material and methods}

Five moorings were deployed in October 2012 (Stuut et al., 2012), of which four were moored along a transect at $12^{\circ} \mathrm{N}$ across the equatorial North Atlantic Ocean, and a fifth at $13^{\circ} \mathrm{N}$ (Fig. 1a). Each mooring is equipped with two sediment traps, at depths of 1200 and 3500 meters below sea level (BSL), or "upper" and "lower", respectively (Fig. 1b, Table 1$)$. The sediment traps are model PPS $5 / 2$ from Technicap that consist of a conical funnel $\left(36^{\circ}\right)$ with a catchment area of $1 \mathrm{~m}^{2}$ and an $8 \mathrm{~mm}$ hexagonal baffle on top to maximize particle collection (Knauer and Asper, 1989) and prevent large swimmers from entering the sediment trap. Underneath the funnel, a rotating carrousel with 24 sampling cups collects discrete samples of the settling particle flux. All sediment traps operated synchronously over pre-programmed intervals of 16 days and performed flawlessly. Tilt meters showed that the sediment traps remained nearly upright for the entire sampling period. With a few exceptions, current velocities, as measured by current meters and acoustic Doppler current profilers, remained well below $12 \mathrm{~cm} \mathrm{~s}^{-1}$, the threshold below which unbiased collection of settling particles occurs (Knauer and Asper, 1989). This paper presents the re- 


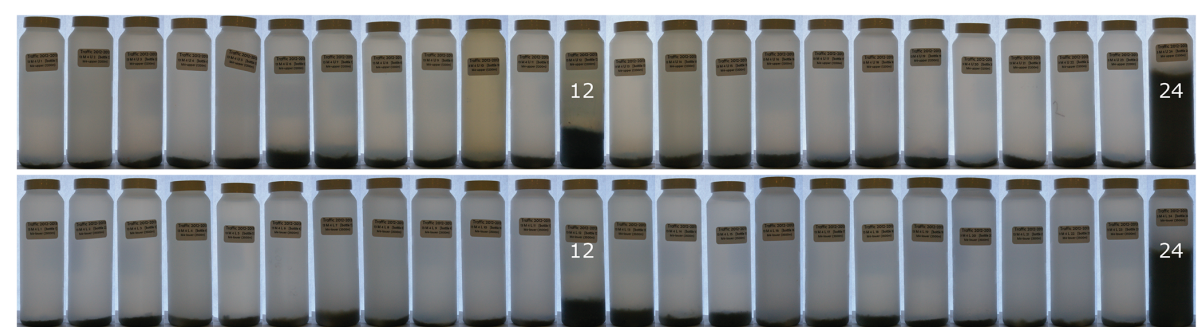

Figure 2. Sediment-trap bottles of the upper $(1200 \mathrm{~m})$ and lower $(3500 \mathrm{~m})$ traps at station $\mathrm{M} 4\left(12^{\circ} \mathrm{N}, 49^{\circ} \mathrm{W}\right)$.

sults of successful sampling by seven sediment traps on the five moorings from 19 October 2012 to 7 November 2013 (Stuut et al., 2013). These include three of the upper (1200 m) sediment traps located at mooring stations M1, M2, and M4, and four lower $(3500 \mathrm{~m})$ sediment traps at stations M2, M3, M4, and M5 (Fig. 1, Table 1). Three of the 10 sediment traps could not be recovered. In addition, seafloor sediments were collected by a multicorer at all five mooring stations, using the top centimeter for comparison with the sediment-trap samples.

Since both the upper and lower traps are recovered for two of the five stations (M2 and M4), this allows for a direct comparison between the two depths. The upper and lower sediment traps are in very good accordance with each other, demonstrated by images of the sediment-trap bottles after recovery (Fig. 2). Two samples, sample 12 and 24, have a much higher flux than the other samples, and these high-flux samples are present in both the upper and lower trap. Since the sampling interval is only 16 days, the downward transport velocity of the sediments between the traps is at least $140 \mathrm{~m} \mathrm{day}^{-1}$ and most likely much higher. These high settling velocities can be reached since the mineral dust particles are not deposited individually but as part of large marine particles like marine snow. These are aggregates $>500 \mu \mathrm{m}$ of organic and inorganic particles of different composition and origin (e.g., Nowald et al., 2015). These particles have settling velocities of approximately $200 \mathrm{mday}^{-1}$, and may increase with increased depth (Berelson, 2002; Nowald et al., 2015). The samples also show that the sediments are deposited in a vertical way down to both sediment traps. It seems, however, that the higher flux observed in sample 12 of the upper trap is distributed over sample 12 and 13 of the lower trap. This demonstrates that there is a small time lag between the two traps, of no more than a few days, due to the time it takes for the particles to settle. This could also be true for sample 24; however, there is no sample directly after the last sample of the sediment trap.

In this paper we argue that the lithogenic particles found in the sediment traps are of aeolian origin. The sediment traps are located far from the continental shelf, so riverine input of sediments is not affecting the samples. Limited influence of major rivers is also visible when looking at (satellite) data of chlorophyll or salinity (see Supplement). In ad-

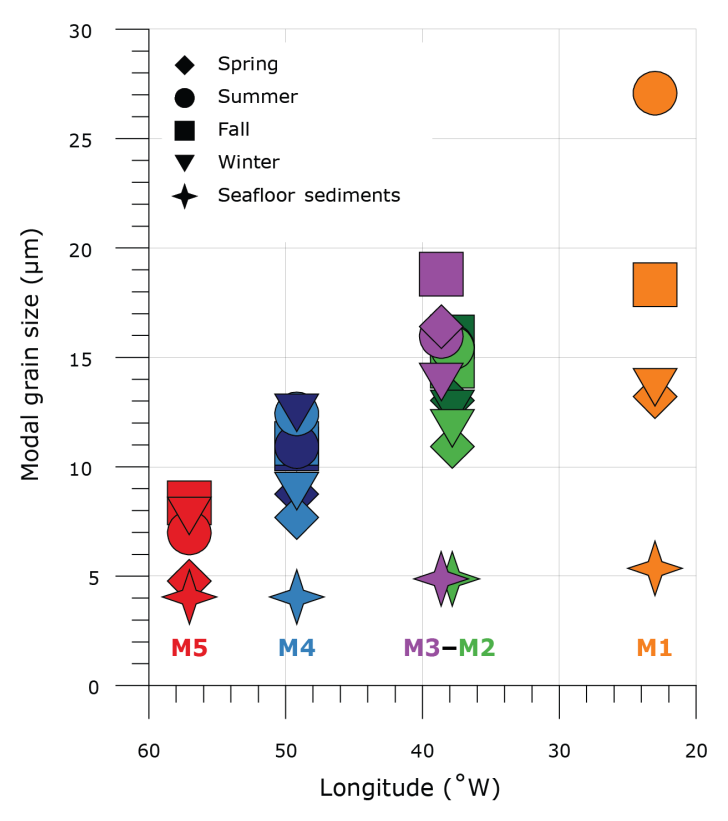

Figure 3. Downwind fining and seasonality in average modal grain size per season for all seven traps (an average of all modal values from the relative volume grain-size distributions, grouped per season), for October 2012-November 2013, and modal grain size of the seafloor sediments (from the grain-size distributions as shown in Fig. 4b) vs. western longitude. For M2 (green) and M4 (blue), lighter colors indicate the upper $(1200 \mathrm{~m})$ trap, and darker colors indicate the lower $(3500 \mathrm{~m})$ trap.

dition, the lower sediment traps are positioned $880-1300 \mathrm{~m}$ above the seafloor, so resuspension of bottom sediments will not affect the sediment-trap samples. When considering the large amounts of Saharan dust being transported across the Atlantic Ocean every year, about $182 \mathrm{Tg}$ (Yu et al., 2015), any other external input is assumed to be negligible. Stuut et al. (2005) also demonstrated the similarity between aerosol samples of Saharan dust collected off western Africa and the lithogenic fraction in sediment traps and seafloor sediments.

Prior to the deployment of each sediment trap, the sampling cups were filled with seawater collected at the deployment site depths, to which a biocide $\left(\mathrm{HgCl}_{2}\right.$; end concentration $1.3 \mathrm{~g} \mathrm{~L}^{-1}$ ) and a $\mathrm{pH}$ buffer (borax, $\mathrm{Na}_{2} \mathrm{~B}_{4} \mathrm{O}_{7} 10 \mathrm{H}_{2} \mathrm{O}$; end concentration $1.3 \mathrm{~g} \mathrm{~L}^{-1}, \mathrm{pH} \approx 8.5$ ) were added, to a den- 
sity slightly higher than the ambient seawater. In the laboratory each sample was sieved through a $1 \mathrm{~mm}$ mesh to remove mostly zooplankton swimmers, then wet-split in five aliquots using a WSD10 rotor splitter (McLane Laboratories, USA). The average weight difference between replicate aliquots of each sample is $2.4 \%(\mathrm{SD}=2.2)$, with $87 \%$ of all samples having a weight difference of $<5 \%$ between splits. The highest deviation was found to be $12 \%$. For grain-size analysis, one of these aliquots was split into another five subsamples $(1 / 25$ of the original sample), which were washed and centrifuged repeatedly at approximately $1800 \times g$ with Milli-Q water to remove the $\mathrm{HgCl}_{2}$, borax, and sea salts.

The sediment traps collect all particles settling down into the ocean, which besides mineral dust includes the skeletons of marine plankton (foraminifera, radiolarians, diatoms, coccolithophores, etc.), organic matter (marine and aerosols from biomass burning) and potentially volcanogenic and cosmogenic particles (Plane, 2012). All these biogenic constituents were chemically removed in three steps to isolate the insoluble or lithogenic dust fraction from all samples, prior to grain-size analysis, following the procedure described by McGregor et al. (2009). Briefly, organic matter was oxidized using $\mathrm{H}_{2} \mathrm{O}_{2}$, followed by dissolving the biogenic carbonates using $\mathrm{HCl}$, and removing biogenic silica by adding $\mathrm{NaOH}$. What remains is the lithogenic fraction, which is considered to consist mainly of dust, as confirmed by microscope analysis (Fig. 5). Indeed, some of the dust particles have a risk of being removed during this process including lithogenic carbonates and organic particles of nonmarine origin. However, lithogenic carbonates are more resistant to the chemical treatment than the biogenic carbonates. Also, since this is the case for every sample analyzed, they can be compared directly to each other. Immediately prior to the grain-size measurements sodium pyrophosphate $\left(\mathrm{Na}_{4} \mathrm{P}_{2} \mathrm{O}_{7} 10 \mathrm{H}_{2} \mathrm{O}\right)$ was added to ensure complete disaggregation of the particles. The particle-size distributions were measured with a Coulter laser diffraction particle sizer (LS13 320 ) with a micro liquid module (MLM) for small-volume samples, and a magnetic stirrer was used to homogenize the sample during analysis. In order to minimize the influence of air bubbles, the system uses degassed water. This resulted in particle-size distributions consisting of 92 size classes ranging from 0.375 to $2000 \mu \mathrm{m}$ describing the equivalent-sphere diameter of the particle. Modal particle size is also expressed as particle diameter. The reproducibility is checked regularly at MARUM, Bremen (Germany), using exactly the same equipment setup as in this study, by J. Titschack. This is performed by replicate analyses of three internal glass-bead standards, and the reproducibility is found to be better than $\pm 0.7 \mu \mathrm{m}$ for the mean and $\pm 0.6 \mu \mathrm{m}$ for the median particle size $(1 \sigma)$. The average standard deviation integrated over all the size classes is better than $\pm 4 \mathrm{vol} \%$.

To determine seasonal changes in dust deposition along the trans-Atlantic transect, the sediment-trap samples are grouped per season. The seasons are defined as follows: (bo-
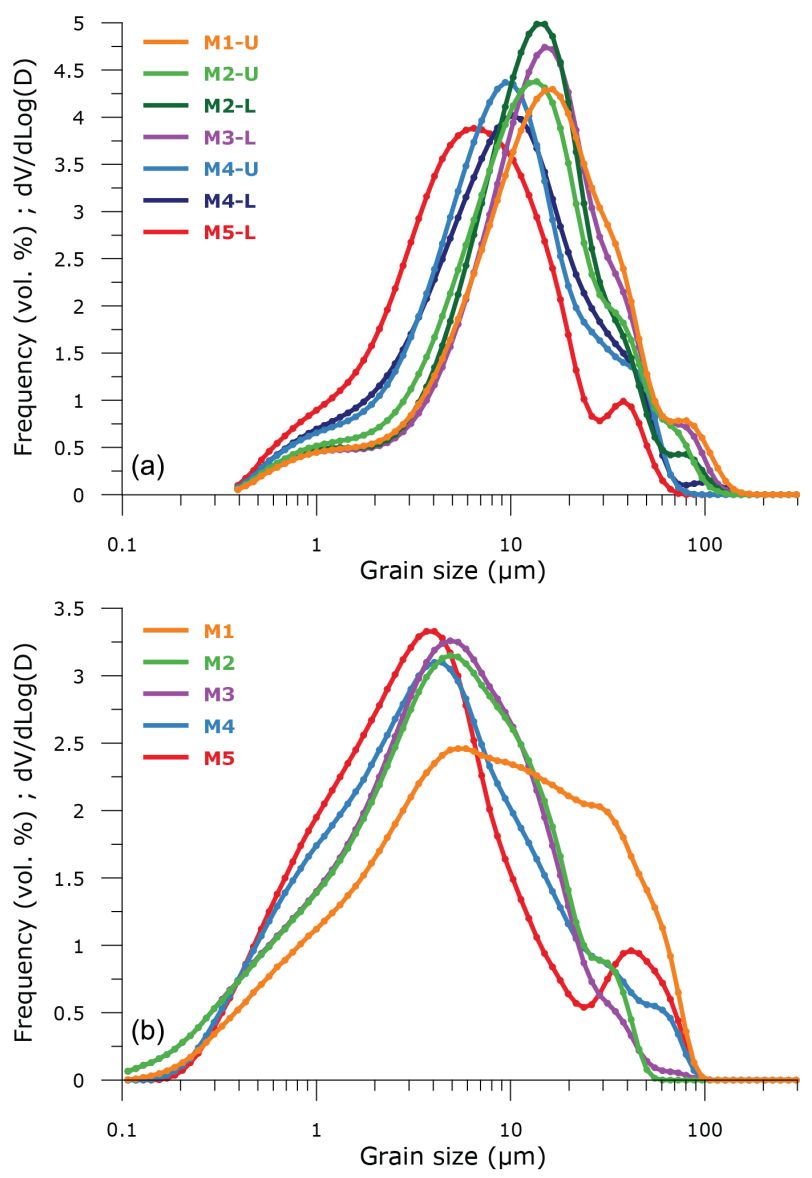

Figure 4. (a) Average volume grain-size distributions of 24 samples from all seven sediment traps, where $\mathrm{U}$ is the upper trap $(1200 \mathrm{~m})$ and $\mathrm{L}$ the lower trap $(3500 \mathrm{~m})$. Collected between October 2012 and November 2013. (b) Grain-size distributions of seafloor sediments at the five mooring stations (M1-M5) along the trans-Atlantic transect.

real) fall includes September, October, and November (SON) of 2012 and 2013; winter includes December, January, and February (DJF) of 2012/2013; spring includes March, April, and May (MAM) of 2013; and summer includes June, July, and August (JJA) of 2013. The dates the samples refer to are the middle date of each 16-day sampling period.

In order to determine the provenance of dust-carrying air layers, 4-day backward trajectories of air parcels were calculated with the Hybrid Single Particle Lagrangian Integrated Trajectory (HYSPLIT) model (Stein et al., 2015), using the GDAS $\left(0.5^{\circ}\right)$ meteorological dataset (http://www.ready.noaa. gov/HYSPLIT.php). The heights of these air layers were chosen in accordance with typical winter and summer dustcarrying air layers (see below), and the starting point of the trajectories is station $\mathrm{M} 1\left(12^{\circ} \mathrm{N}, 23^{\circ} \mathrm{W}\right)$.

Data for aerosol optical depth (AOD) and daily precipitation were obtained from the Giovanni online data system, developed and maintained by the NASA GES DISC. The AOD 

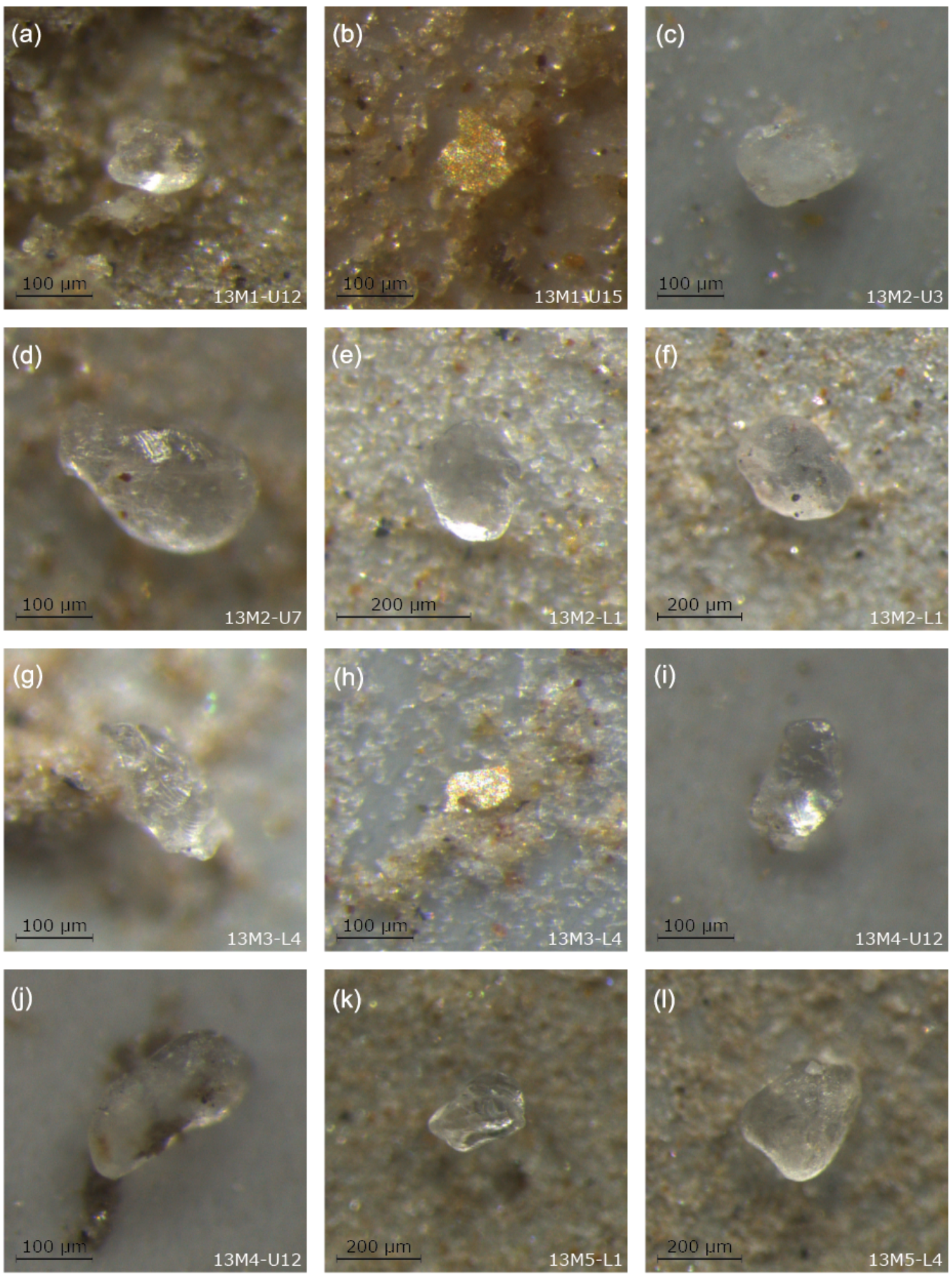

Figure 5. Light-microscope images of large dust particles from the sediment-trap samples. Names in the lower-right corners: 13Mx denotes the station (see Table 1 for the exact locations). U and L denote upper $(1200 \mathrm{~m})$ and lower $(3500 \mathrm{~m})$ traps, respectively, followed by the sample number (out of a total of 24). (a) Quartz particle (diameter approximately $140 \mu \mathrm{m})$, (b) mica particle $(120 \mu \mathrm{m})$, (c) quartz particle $(180 \mu \mathrm{m}),(\mathbf{d})$ quartz particle $(270 \mu \mathrm{m})$, (e) quartz particle $(180 \mu \mathrm{m})$, (f) quartz particle $(290 \mu \mathrm{m})$, (g) quartz particle $(200 \mu \mathrm{m})$, (h) mica particle $(85 \mu \mathrm{m})$, (i) quartz particle $(180 \mu \mathrm{m})$, (j) quartz particle $(250 \mu \mathrm{m}),(\mathbf{k})$ quartz particle $(240 \mu \mathrm{m})$, and (l) quartz particle $(300 \mu \mathrm{m})$. 

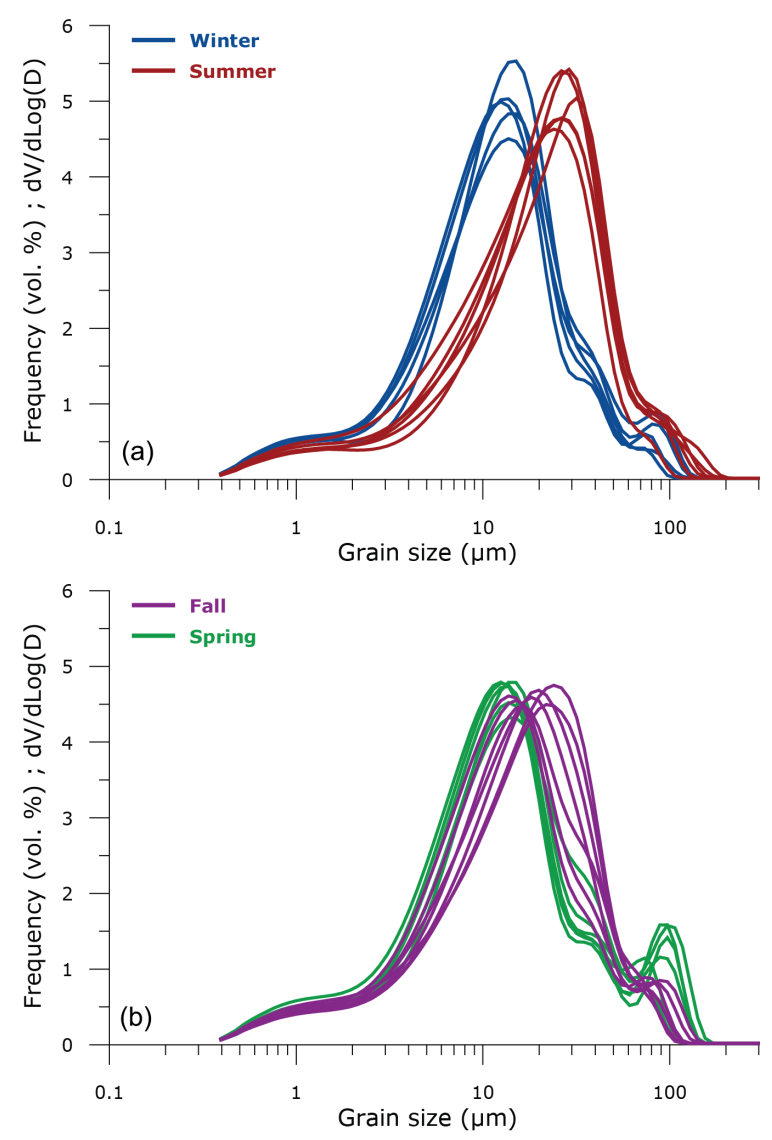

rapidly fining westward towards M5. Also, the seafloor sediments show the same clear and almost linear downwind trend of decreasing particle size (Fig. 3). However, grain sizes in the seafloor sediments are substantially finer than found in the sediment-trap samples, and the downwind decrease in grain size is also less steep for the seafloor sediments. All traps show a shoulder towards the coarse end of the grainsize distribution, which is most prominent at station M5 (Fig. 4a). This shows that coarse particles are not only deposited at proximal locations but also transported over great distances. These shoulders are also found in the seafloor sediments (Fig. 4b). They include "giant" particles of more than $100 \mu \mathrm{m}$, which are observed as far west as station M5 $\left(57^{\circ} \mathrm{W}\right.$; approximately $4400 \mathrm{~km}$ from the African coast, and thus ever further from the actual dust source), and consist of both platy mica and rounded quartz particles (Fig. 5). Furthermore, the average grain-size distributions show that the differences between stations are larger than between the upper $(1200 \mathrm{~m})$ and lower $(3500 \mathrm{~m})$ traps at stations M2 and M4 (Fig. 4a). The grain-size distributions of the seafloor sediments show that the dust at station M1 is the least sorted, meaning that the widest range of particles of different sizes is deposited closest to the source (Fig. 4b).

\subsection{Seasonal grain-size trends}

The particle size of Saharan dust deposited in the Atlantic Ocean changes seasonally, and is clearly coarser in summer than in winter at station M1 (Fig. 6a). During spring, a coarse shoulder is present in the grain-size distributions (Fig. 6b), more prominent than during the other seasons. Also, modal grain sizes illustrate this seasonality, varying between 12.5 and $15 \mu \mathrm{m}$ from October 2012 to May 2013 (fall to spring), followed by a sharp increase to about $30 \mu \mathrm{m}$ in June 2013, and stays coarse for the entire summer season (Fig. 7a) at station M1. Grain sizes decrease again in late August, and keep decreasing throughout the fall of 2013. At M2 the modal particle size of the upper trap decreases from fall to winter, from 15 to about $10 \mu \mathrm{m}$, followed by an increase to around $15 \mu \mathrm{m}$ in May, continuing into summer and fall 2013. At M4 particle sizes of the upper trap decrease from $10 \mu \mathrm{m}$ in fall 2012 to $7 \mu \mathrm{m}$ in mid-spring 2013 , after which they increase to around $12.5 \mu \mathrm{m}$ throughout summer and fall 2013 .

Overall, the particle size at the three sites show the same seasonality, with coarser dust in summer and fall and finer dust in winter and spring (Fig. 7a). However, the difference in particle size between these seasons is greatest at M1, close to the source (Fig. 3). Here, particles are also least sorted and have the widest range in particle size, which gradually decreases westward towards M5. However, seasonal trends in modal grain size are more pronounced in the three upper traps at $1200 \mathrm{~m}$ than in the four lower sediment traps at $3500 \mathrm{~m}$ (Fig. 7b). In the lower traps, the modal particle size at the more northern station M2 is slightly finer than at the more southern station M3 from fall 2012 to spring 2013, 

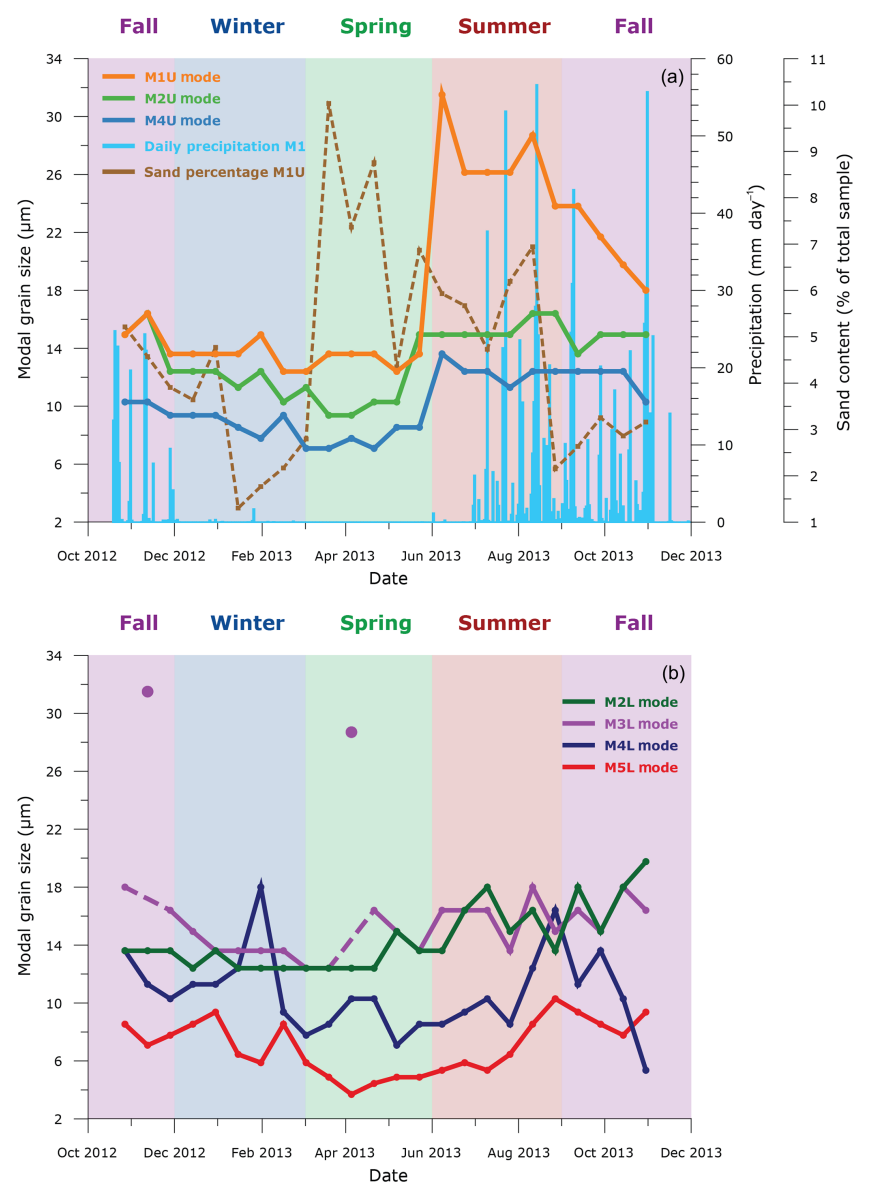

Figure 7. (a) Modal particle diameter of dust collected by the three upper $(1200 \mathrm{~m})$ sediment traps at stations M1, M2, and M4 (left axis), daily precipitation (right axis; TRMM) and percentage of sand particles $(>63 \mu \mathrm{m})$ (far right axis) at station M1. (b) Modal particle diameter of dust collected by the three lower $(3500 \mathrm{~m})$ sediment traps at station M2, M3, M4, and M5. The two points that are not connected in series M3L are considered outliers.

with the exception of two samples that show unusually high modal grain sizes (in November 2012 and April 2013, shown as "outliers" in Fig. 7b). From summer 2013 onwards, the modal grain size of M2 and M3 converge, with synchronous fluctuations between 14 and $18 \mu \mathrm{m}$. Seasonality at M4 is even weaker, with grain sizes varying between 5 and $18 \mu \mathrm{m}$. At the westernmost station, M5 modal particle size ranges between 4 and $10 \mu \mathrm{m}$, with a decrease in spring 2013 and an increase in summer. In all seven traps, dust is finest during spring. Comparison of modal grain sizes found in the upper $(1200 \mathrm{~m})$ and lower $(3500 \mathrm{~m})$ traps from stations M2 and M4 shows that the lower sediment traps have slightly coarser dust than the upper traps (Fig. 7).

\section{Discussion}

The grain size of dust decreases with increased distance from the source (Glaccum and Prospero, 1980; Goudie and Middleton, 2006; Mahowald et al., 2014; Stuut et al., 2005): coarse particles have a higher settling velocity and smaller particles can be transported over greater distances (Gillette, 1979; Tsoar and Pye, 1987). This mechanism accounts for the downwind fining observed in both the sediment traps and the seafloor sediments along the trans-Atlantic transect (Fig. 3). However, we observed giant particles $(\geq 100 \mu \mathrm{m})$ as far west as station M5 $\left(57^{\circ} \mathrm{W}\right.$; approximately $4400 \mathrm{~km}$ from the African coast; Fig. 5), and mica particles, whose platy shape allows for aerial transport over greater distances (Stuut et al., 2005). Only a handful of these coarse particles are found in the samples; however, when considering these are $1 / 25$ of the original samples, collecting sediments over $1 \mathrm{~m}^{2}$ of ocean, over a time period of 16 days, the amount of giant particles being transported over the Atlantic Ocean every year can be considered to be substantial. Such coarse particles are generally not incorporated into climate models (Kok, 2011).The underestimation of the coarse size fraction in climate models may have its origin in the sampling of dust of specific size classes, e.g., $\mathrm{PM}_{10}$ and $\mathrm{PM}_{2.5}$, which form the basis of the guidelines from the World Health Organization (WHO, 2006) on fine-grained particles.

Since the seafloor sediments represent a longer time average of Saharan dust deposition than the sediment-trap samples, the downwind fining is implied to be a long-lived trend. However, the modal particle size of the sediment-trap samples is substantially coarser than that of the seafloor sediments at the same stations along the transect. The particlesize distributions found in the sediment-trap samples closely resemble Saharan dust sampled directly from the atmosphere by shipboard dust samplers along a transect off the western African coast, which has modal grain sizes varying between 8 and $42 \mu \mathrm{m}$ (Stuut et al., 2005). This is in close resemblance with the observed modal grain size of $4-32 \mu \mathrm{m}$ in the sediment traps. By contrast, modal grain sizes in the underlying seafloor sediments range between 4 and $5.5 \mu \mathrm{m}$. Since the seafloor sediments represent a longer time period, this suggests that Saharan dust was significantly finer in the recent past and increased over the last centuries. Deposition of coarser dust is in line with increased emission as a result of human activity since the 19th century due to commercial agriculture (Mulitza et al., 2010). Increased human activity in the source region not only increases dust emissions but also enables larger particles to be emitted (McTainsh et al., 1997), which is one possible mechanism that could cause the particle size of the deposited Saharan dust to become gradually coarser over time, as we observe now in the sediment traps. However, we do not exclude other mechanisms that could be responsible for the change in particle size of mineral dust as deposited along the sampled transect. 

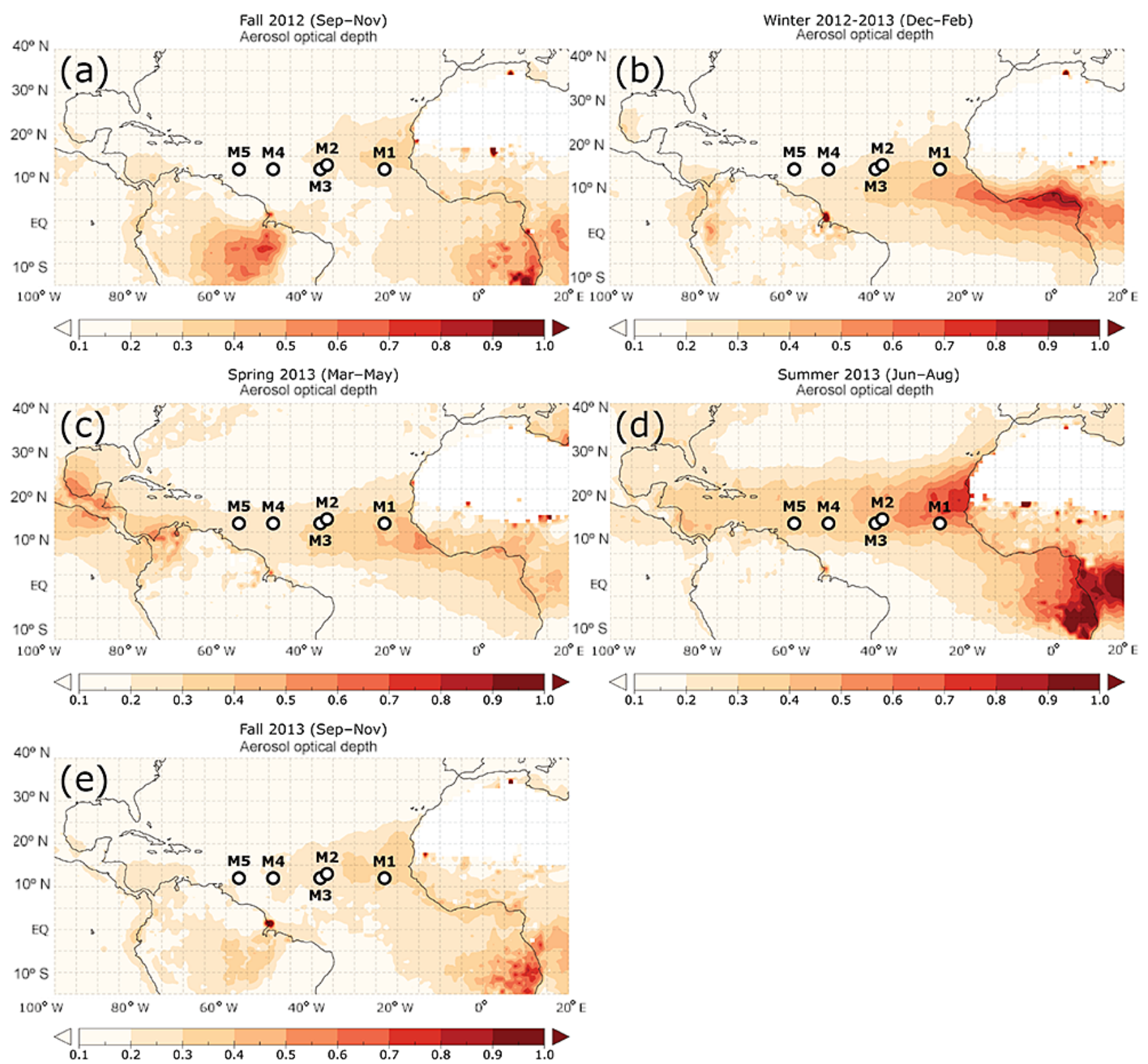

Figure 8. Three-month average aerosol optical depth (AOD) for the sampled seasons, from MODIS Terra. (a) Fall 2012 (SON), (b) winter 2012-2013 (DJF), (c) spring 2013 (MAM), (d) summer 2013 (JJA), and (e) fall 2013 (SON). Stations M1-M5 are marked with white-filled black circles.

The seasonal variability in particle size can be the result of several factors. First, it could result from the seasonal movement of the dust cloud, associated with the latitudinal movement of the ITCZ (Nicholson, 2000). As a result, in summer, dust is transported at more northern latitudes than in winter, as indicated by the aerosol optical depth (AOD) data (Fig. 8). These aerosols can include sea salts, organic and black carbon, sulfates, and mineral dust. However, the aerosols over our study area are mostly mineral dust originating from the African continent (Yu et al., 2015). Adams et al. (2012) also speculate that smoke is not transported over great distances, as opposed to mineral dust. In summer, when AOD values are highest, the cloud is located at its northernmost position (Fig. 8d). Aerosol concentrations are lowest during fall (Fig. 8a and e), and during winter the cloud is located in its southernmost position (Fig. 8b). However, during winter the aerosols may receive a higher contribution from soot by bushfires released more to the south (as also visible during the other seasons), thereby moving this high-AOD cloud southward and possibly falsely implying the latitudinal movement of the dust cloud. 


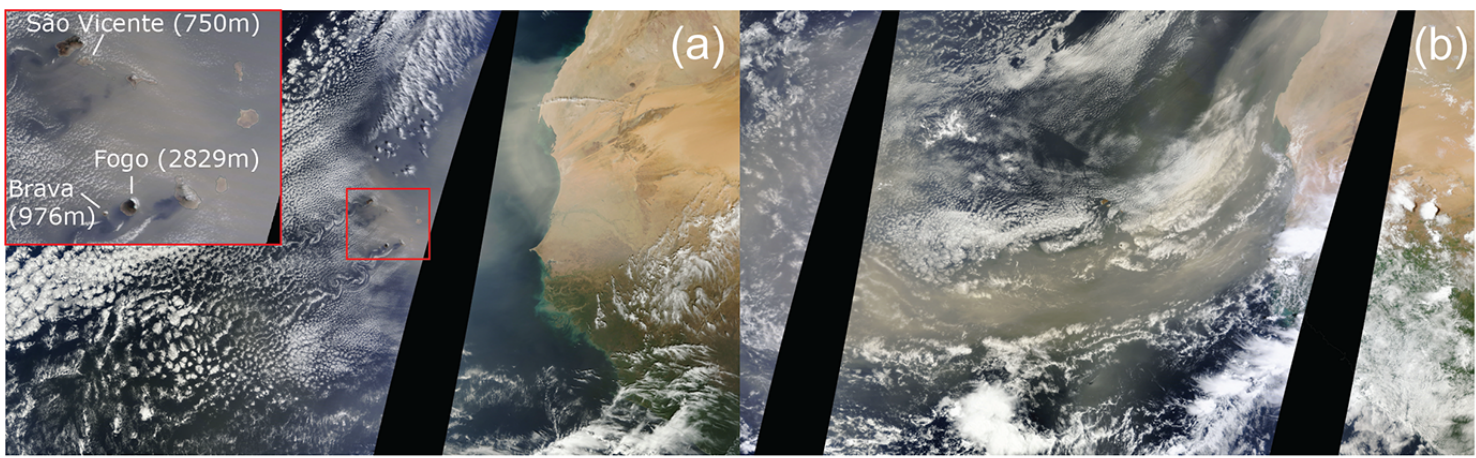

NOAA backward trajectories ending at 1400 UTC 07 Jan 2013

NOAA backward trajectories ending at 1400 UTC 31 Jul 2013
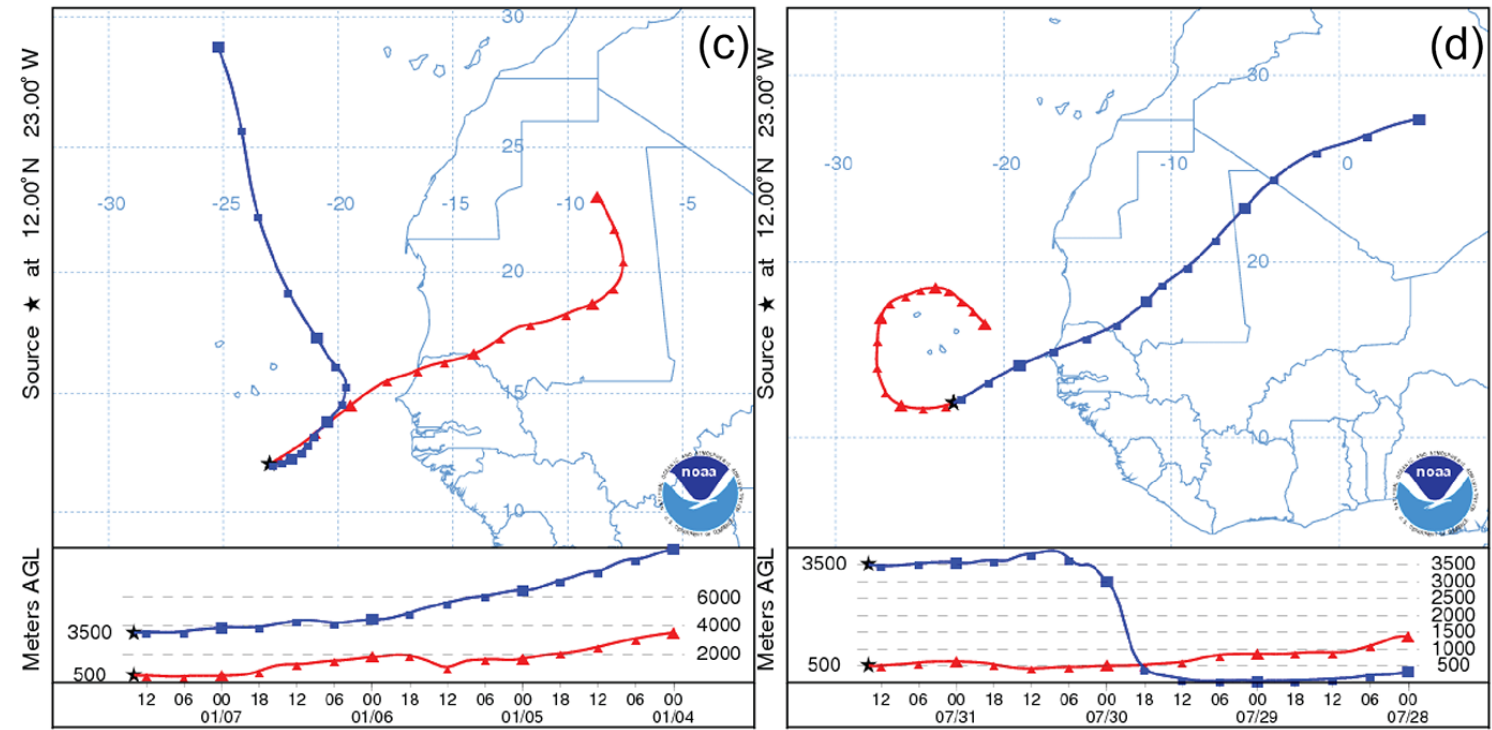

Figure 9. (a) Satellite images of typical winter dust transport, with a close-up of the Cabo Verde islands (7 January 2013) and (b) typical summer dust transport (31 July 2013) over the Cabo Verde islands, at relatively low and high altitudes, respectively. Images from NASA Worldview, MODIS Terra satellite. Black areas are artifacts from satellite passage. (c, d) Concurrent 4-day backward trajectories of air parcels from station M1 (star), at $500 \mathrm{~m}$ (red) and $3500 \mathrm{~m}$ (blue) AGL, showing trajectory maps (top) and elevation profiles (bottom). (c) Ending at 7 January 2013, and (d) ending at 31 July 2013.

This seasonal, latitudinal shift of the dust cloud is reflected in the samples from stations M2 and M3, which are positioned at $1^{\circ}$ northern latitude from each other. During winter, modal grain sizes at the northern station $\left(\mathrm{M} 2,13^{\circ} \mathrm{N}\right)$ are finer than at the southern station $\left(\mathrm{M} 3,12^{\circ} \mathrm{N}\right)$, while they are similar at both stations during summer (Fig. 7b). Thus, during winter the northern station M2 does not receive the same dust as station M3, since the dust cloud is located more to the south. In summer the dust cloud is located more to the north, delivering coarser particles and at the latitude of both stations. However, the difference in grain size between the two traps is small, due to the close proximity of the two stations (about $200 \mathrm{~km}$ ). In addition, the seasonal shift of the ITCZ also causes a latitudinal shift of the seasonal rain belt, affecting different sources during the year (Nicholson, 2000) and changing the amount and location of wet deposition of dust. An alternative explanation is provided by different wind systems that are active throughout the year, along different trajectories and at different wind speeds. These can entrain dust from different source areas. The elevation of these wind systems, in combination with wind speeds and the particle size of the source soils, determines the particle-size distributions of the entrained dust (Marticorena, 2014; Tsoar and Pye, 1987) and is further influenced during transport and deposition, creating different grain-size signatures for summer and winter dust.

In winter, dust is transported at lower altitudes than during summer (Adams et al., 2012; Tsamalis et al., 2013). This is evidenced by satellite images of the Cabo Verde islands, which show the high mountain tops (highest point is Fogo at $2829 \mathrm{~m}$ ) piercing through the dust cloud, deflecting it around the islands (Fig. 9a). The lowest peak that is still visible above the dust cloud is Brava $(976 \mathrm{~m})$, but the top of São Vicente $(750 \mathrm{~m})$ is not. This means that the top of the 
dust cloud is at an elevation between 976 and $750 \mathrm{~m}$. In summer, dust is transported at much higher altitudes than winter, covering the Cabo Verde islands in a thick blanket of dust (Fig. 9b), meaning that the top of the cloud is at an elevation of at least $2829 \mathrm{~m}$. During summer, dust is transported in the high-altitude SAL (Carlson and Prospero, 1972; Kanitz et al., 2014; Prospero and Carlson, 1972; Tsamalis et al., 2013). Mahowald et al. (2014) argue that the dust particle size does not depend on wind speeds at emission. However, high wind velocities in the SAL of $>7 \mathrm{~ms}^{-1}$ (Tsamalis et al., 2013) enable coarser dust particles to remain in suspension in summer, and due to the high altitude, these coarse particles are transported over great distances. In addition, increased convection in the source areas in summer, related to larger differences in temperature, can result in the uplift of coarser dust particles (Heinold et al., 2013).

Four-day backward trajectories of air parcels also illustrate the difference in the elevation of the dust-transporting air layers between winter and summer (Fig. 9c and d). The altitudes of the starting points of these backward trajectories were chosen in accordance with the hypothesized heights of the dust-carrying air layers, as demonstrated in Fig. 9a and $\mathrm{b}$, with the lowest $(500 \mathrm{~m})$ elevation representing winter dust transport and the highest $(3500 \mathrm{~m})$ elevation representing summer dust. In winter (Fig. 9c), the higher trajectory is not originating from the African continent, and therefore the winds at these altitude are unlikely to transport dust to the sample location. The lower trajectory has a more eastern origin, and air layers at this altitude could be transporting dust (Fig. 9a), which is picked up from the surface and brought to higher altitudes. By contrast, in summer (Fig. 9d), this situation is reversed: the higher trajectory has a more continental origin and is the most likely dust-carrying air layer over the lower trajectory. The elevation profile shows that this high-elevation trajectory started at lower altitudes, but upon reaching the coastline it was uplifted to about $3500 \mathrm{~m}$ AGL (Fig. 9d, bottom panel). This is in accordance with how the SAL is described: dust-carrying air from the continent is uplifted by a cool marine inversion layer (Carlson and Prospero, 1972). This inverted air layer is visible in the $500 \mathrm{~m}$ air layer, moving in an opposite direction, from west to east. After this sharp increase in altitude, the trajectory decreases in altitude, which persists across the Atlantic Ocean (Tsamalis et al., 2013).

The summer season is also characterized by an increased number of more intense dust storms (e.g., Adams et al., 2012). From May to September, dust is almost continuously emitted from the African continent, as shown by satellite images (MODIS Terra and Aqua satellites; NASA Worldview). Within 5 days, the dust cloud propagates towards the Caribbean and becomes progressively thinner by dust deposition in the Atlantic Ocean along its track. Increased deposition of coarse particles can also be caused by increased precipitation in summer and fall, as opposed to almost no precipitation in winter and spring (Fig. 7a). This was also noted off northwestern Africa related to wet deposition by Friese et al. (2016). Increased precipitation at station M1 seems to coincide with increased modal grain sizes, and this relation commences with lowest precipitation in early June 2013. This suggests that a small amount of precipitation is already sufficient to wash out the suspended dust from the atmosphere by wet deposition.

At M1, the percentage of sand-sized particles $(>63 \mu \mathrm{m})$ increases sharply in spring, while modal grain sizes increase in summer (Fig. 7a). This increase in coarse particles is related to coarse shoulders in the grain-size distributions of the spring samples (Fig. 6b) that are absent or less prominent in fall, winter, and summer (Fig. 6a and b). These coarse particles mostly include micas: due to their platy shape, these particles have a different aerodynamical behavior than more spherical quartz particles and are therefore more easily transported by wind than spherical particles with a similar diameter (Stuut et al., 2005). However, large $(\geq 100 \mu \mathrm{m})$, more spherical particles were also observed in the samples, at very large distances from the source (Fig. 5). These coarse particles, visible in the grain-size distributions as coarse shoulders, are found in all the traps at all stations and appear to be most frequent during spring. An increased number of coarse particles during spring could mean that the dust originates from a different source area. Backward trajectories calculated over the entire sampling period do not show this. However, these backward trajectories serve only as an indicator for air-layer trajectories, but from these it does not become clear what surface conditions contributed to the uplift of particles in the long-distance transporting air layers.

The lower $(3500 \mathrm{~m})$ traps show less seasonality and are generally slightly coarser than the upper $(1200 \mathrm{~m})$ traps. This may be due to the disaggregation of marine snow, releasing the individual dust particles and thus decreasing their settling velocity. Therefore, it would take longer for particles to reach the lower traps at $3500 \mathrm{~m}$, especially very fine particles, and as a result the particle-size distributions lose their seasonal characteristics. This would also explain why the dust particles in the lower traps (at M2 and M4) are slightly coarser than their upper counterparts, since these coarse particles settle more quickly and the very fine particles may not reach the lower traps.

\section{Conclusions}

We have shown seasonal and spatial changes in Saharan mineral dust transport and deposition across the Atlantic Ocean by means of sediment-trap sampling between October 2012 and November 2013, and spatial changes in the seafloor sediments at the same stations. Our results show strong seasonal variations and significant fining in particle size with increasing distance from the source in the sediment-trap samples, with modal particle diameters ranging from 4 to $32 \mu \mathrm{m}$. Coarser dust is found in the sediment traps as opposed to 
the seafloor sediments, which is in line with increased emission and coarser dust due to the onset of commercial agriculture in the 19th century, and is a possible explanation for the difference in particle size between the two records. A downwind decreasing particle size reflects the greater gravitational settling velocity of coarse particles, resulting in deposition closer to the source. The largest seasonal difference in particle size occurs closest to the source; however, the lower sediment traps $(3500 \mathrm{~m})$ show less seasonality than the upper sediment traps $(1200 \mathrm{~m})$. This may be due to marine snow disaggregating, decreasing the settling velocity of individual dust particles, resulting in a decreased expression of the seasonal particle-size signatures. Coarser grain sizes during summer and finer during winter and spring suggest (1) summer transport at higher elevations of up to $5 \mathrm{~km}$ within the Saharan Air Layer at high wind speeds $\left(>7 \mathrm{~ms}^{-1}\right)$ compared to winter transport; (2) coupling to the latitudinal movement of the dust cloud with the ITCZ; and (3) increased emission by more frequent dust storms in summer combined with wet deposition by increased precipitation. Increased contribution of coarse $(>63 \mu \mathrm{m})$ particles in spring is likely caused by large platy minerals (e.g., micas) of small aerodynamic size that are easily uplifted and transported, possibly from a different source area. These coarse particles are transported thousands of kilometers away from the Saharan source. Multiple-year samples from this transect and coupled dust deposition fluxes should clarify which of the abovementioned processes are more dominant in order for them to be incorporated into, for example, climate models and climate reconstructions. Our results contribute to a better understanding of the seasonal and spatial variability of Saharan dust, which still remains a poorly constrained factor in global climate.

\section{Data availability}

All data used in this manuscript have been stored at https: //doi.pangaea.de/10.1594/PANGAEA.863030 (van der Does et al., 2016).

\section{The Supplement related to this article is available online at doi:10.5194/acp-16-13697-2016-supplement.}

Acknowledgements. We thank the captain, crew, and scientists of RV Meteor cruise M89 and RV Pelagia cruise 64PE378 for deployment and retrieval of the sediment-trap moorings. Funding is provided by NWO with the TRAFFIC project 822.01 .008 , as well as by the ERC with starting grant 311152: DUSTTRAFFIC. We thank J. Schwarz and the three anonymous reviewers for their helpful comments.

Edited by: J. Schwarz

Reviewed by: three anonymous referees

\section{References}

Adams, A. M., Prospero, J. M., and Zhang, C.: CALIPSODerived Three-Dimensional Structure of Aerosol over the Atlantic Basin and Adjacent Continents, J. Climate, 25, 6862-6879, doi:10.1175/jcli-d-11-00672.1, 2012.

Armstrong, R. A., Lee, C., Hedges, J. I., Honjo, S., and Wakeham, S. G.: A New, Mechanistic Model for Organic Carbon Fluxes in the Ocean Based on the Quantitative Association of POC with Ballast Minerals, Deep-Sea Res. Pt. II, 49, 219-236, 2002.

Berelson, W. M.: Particle settling rates increase with depth in the ocean, Deep-Sea Res. Pt. II, 49, 237-251, 2002.

Betzer, P. R., Carder, K. L., Duce, R. A., Merrill, J. T., Tindale, N. W., Uematsu, M., Costello, D. K., Young, R. W., Feely, R. A., Breland, J. A., Bernstein, R. E., and Greco, A. M.: Long-Range Transport of Giant Mineral Aerosol-Particles, Nature, 336, 568571, doi:10.1038/336568a0, 1988.

Bressac, M., Guieu, C., Doxaran, D., Bourrin, F., Desboeufs, K., Leblond, N., and Ridame, C.: Quantification of the lithogenic carbon pump following a simulated dust-deposition event in large mesocosms, Biogeosciences, 11, 1007-1020, doi:10.5194/bg-11-1007-2014, 2014.

Carlson, T. N. and Prospero, J. M.: The Large-Scale Movement of Saharan Air Outbreaks over the Nothern Equatorial Atlantic, J. Appl. Meteorol., 11, 283-297, 1972.

Claquin, T., Roelandt, C., Kohfeld, K. E., Harrison, S. P., Tegen, I., Prentice, I. C., Balkanski, Y., Bergametti, G., Hansson, M., Mahowald, N., Rodhe, H., and Schulz, M.: Radiative Forcing of Climate by Ice-Age Atmospheric Dust, Clim. Dynam., 20, 193202, doi:10.1007/s00382-002-0269-1, 2003.

Croot, P. L., Streu, P., and Baker, A. R.: Short Residence Time for Iron in Surface Seawater Impacted by Atmospheric Dry Deposition From Saharan Dust Events, Geophyis. Res. Lett., 31, L23S08, doi:10.1029/2004GL020153, 2004.

d'Almeida, G. A. and Schütz, L.: Number, Mass and Volume Distributions of Mineral Aerosol and Soils of the Sahara, J. Climate Appl. Meteorol., 22, 233-243, 1983.

Fischer, G., Karakas, G., Blaas, M., Ratmeyer, V., Nowald, N., Schlitzer, R., Helmke, P., Davenport, R., Donner, B., Neuer, S., and Wefer, G.: Mineral Ballast and Particle Settling Rates in the Coastal Upwelling System off NW Africa and the South Atlantic, Int. J. Earth Sci. (Geol. Rundsch.), 98, 281-298, doi:10.1007/s00531-007-0234-7, 2007.

Fischer, G. and Karakas, G.: Sinking rates and ballast composition of particles in the Atlantic Ocean: implications for the organic carbon fluxes to the deep ocean, Biogeosciences, 6, 85102, doi:10.5194/bg-6-85-2009, 2009.

Friese, C. A., van der Does, M., Merkel, U., Iversen, M. H., Fischer, G., and Stuut, J.-B. W.: Environmental factors controlling the seasonal variability in particle size distribution of modern Saharan dust deposited off Cape Blanc, Aeolian Res., 22, 165-179, doi:10.1016/j.aeolia.2016.04.005, 2016.

Gillette, D. A.: Environmental Factors Affecting Dust Emission by Wind Erosion, in: Saharan Dust, edited by: Morales, C., John Wiley \& Sons, 71-91, 1979.

Glaccum, R. A. and Prospero, J. M.: Saharan Aerosols over the Tropical North-Atlantic - Mineralogy, Mar. Geol., 37, 295-321, doi:10.1016/0025-3227(80)90107-3, 1980. 
Goudie, A. S. and Middleton, N. J.: Saharan Dust Storms: Nature and Consequences, Earth-Sci. Rev., 56, 179-204, doi:10.1016/s0012-8252(01)00067-8, 2001.

Goudie, A. S. and Middleton, N. J.: Desert Dust in the Global System, Springer Berlin Heidelberg New York, 2006.

Grini, A. and Zender, C. S.: Roles of Saltation, Sandblasting, and Wind Speed Variability on Mineral Dust Aerosol Size Distribution During the Puerto Rican Dust Experiment (PRIDE), J. Geophys. Res.-Atmos., 109, D07202, doi:10.1029/2003jd004233, 2004.

Heinold, B., Knippertz, P., Marsham, J. H., Fiedler, S., Dixon, N. S., Schepanski, K., Laurent, B., and Tegen, I.: The role of deep convection and nocturnal low-level jets for dust emission in summertime West Africa: Estimates from convectionpermitting simulations, J. Geophys. Res.-Atmos., 118, 43854400, doi:10.1002/jgrd.50402, 2013.

Highwood, E. J. and Ryder, C. L.: Radiative Effects of Dust, in: Mineral Dust, A Key Player in the Earth System, edited by: Knippertz, P. and Stuut, J. B. W., Springer, Springer Science + Business Media Dordrecht, 267-286, 2014.

Holz, C., Stuut, J. B. W., and Henrich, R.: Terrigenous Sedimentation Processes along the Continental Margin off NW Africa: Implications from Grain-Size Analysis of Seabed Sediments, Sedimentology, 51, 1145-1154, doi:10.1111/j.13653091.2004.00665.x, 2004.

Holz, C., Stuut, J. B. W., HenrIch, R., and Meggers, H.: Variability in Terrigenous Sedimentation Processes off Northwest Africa and its Relation to Climate Changes: Inferences from Grain-Size Distributions of a Holocene Marine Sediment Record, Sediment. Geol., 202, 499-508, doi:10.1016/j.sedgeo.2007.03.015, 2007.

IPCC: Climate Change 2013: The Physical Science Basis. Controbution of Working Group I to the Fifth Assessment Report of the Intergovernmental Panel on Climate Change, edited by: Stocker, T. F., Qin, D., Plattner, G.-K., Tignor, M., Allen, S. K., Boschung, J., Nauels, A., Xia, Y., Bex, V., and Midgley, P. M., Cambridge University Press, Cambridge, UK and New York, NY, USA, 1535 pp., 2013.

Kanitz, T., Engelmann, R., Heinold, B., Baars, H., Skupin, A., and Ansmann, A.: Tracking the Saharan Air Layer with shipborne lidar across the tropical Atlantic, Geophys. Res. Lett., 41, 10441050, doi:10.1002/2013GL058780, 2014.

Klaas, C. and Archer, D. E.: Association of Sinking Organic Matter with Various Types of Mineral Ballast in the Deep Sea: Implications for the Rain Ratio, Global Biogeochem. Cy., 16, 63-61-6314, doi:10.1029/2001GB001765, 2002.

Knauer, G. and Asper, V.: Sediment Trap Technology and Sampling: US Global Ocean Flux Study, WHOI, US GOFS Planning Report, 1989.

Kok, J. F.: A Scaling Theory for the Size Distribution of Emitted Dust Aerosols Suggests Climate Models Underestimate the Size of the Global Dust Cycle, P. Natl. Acad. Sci. USA, 108, 10161021, doi:10.1073/pnas.1014798108, 2011.

Mahowald, N., Albani, S., Kok, J. F., Engelstaeder, S., Scanza, R., Ward, D. S., and Flanner, M. G.: The Size Distribution of Desert Dust Aerosols and its Impact on the Earth System, Aeolian Res., 15, 53-71, doi:10.1016/j.aeolia.2013.09.002, 2014.

Marticorena, B.: Dust Production Mechanisms, in: Mineral Dust, A Key Player in the Earth System, edited by: Knippertz, P. and
Stuut, J. B. W., Springer, Springer Science + Business Media Dordrecht, 93-120, 2014.

Martin, J. H. and Fitzwater, S. E.: Iron-Deficiency Limits Phytoplankton Growth in the Northeast Pacific Subarctic, Nature, 331, 341-343, doi:10.1038/331341a0, 1988.

McGregor, H. V., Dupont, L., Stuut, J. B. W., and Kuhlmann, H.: Vegetation change, goats, and religion: a 2000-year history of land use in southern Morocco, Quaternary Sci. Rev., 28, 1434 1448, doi:10.1016/j.quascirev.2009.02.012, 2009.

McTainsh, G. H., Nickling, W. G., and Lynch, A. W.: Dust Deposition and Particle Size in Mali, West Africa, Catena, 29, 307-322, doi:10.1016/S0341-8162(96)00075-6, 1997.

Middleton, N. J., Betzer, P. R., and Bull, P. A.: Long-Range Transport of "Giant" Aeolian Quartz Grains: Linkage with Discrete Sedimentary Sources and Implications for Protective Particle Transfer, Mar. Geol., 177, 411-417, doi:10.1016/s00253227(01)00171-2, 2001.

Moulin, C., Lambert, C. E., Dulac, F., and Dayan, U.: Control of Atmospheric Export of Dust from North Africa by the North Atlantic Oscillation, Nature, 387, 691-694, 1997.

Mulitza, S., Prange, M., Stuut, J. B., Zabel, M., von Dobeneck, T., Itambi, A. C., Nizou, J., Schulz, M., and Wefer, G.: Sahel Megadroughts Triggered by Glacial Slowdowns of Atlantic Meridional Overturning, Paleoceanography, 23, PA4206, doi:10.1029/2008pa001637, 2008.

Mulitza, S., Heslop, D., Pittauerova, D., Fischer, H. W., Meyer, I., Stuut, J. B., Zabel, M., Mollenhauer, G., Collins, J. A., Kuhnert, H., and Schulz, M.: Increase in African Dust Flux at the Onset of Commercial Agriculture in the Sahel Region, Nature, 466, 226228, doi:10.1038/nature09213, 2010.

Nicholson, S. E.: The Nature of Rainfall Variability over Africa on Time Scales of Decades to Millenia, Global Planet. Change, 26, 137-158, doi:10.1016/s0921-8181(00)00040-0, 2000.

Nowald, N., Iversen, M. H., Fischer, G., Ratmeyer, V., and Wefer, G.: Time Series of In-Situ Particle Properties and Sediment Trap Fluxes in the Coastal Upwelling Filament off Cape Blanc, Mauritania, Prog. Oceanogr., 137, 1-11, doi:10.1016/j.pocean.2014.12.015, 2015.

Otto, S., de Reus, M., Trautmann, T., Thomas, A., Wendisch, M., and Borrmann, S.: Atmospheric radiative effects of an in situ measured Saharan dust plume and the role of large particles, Atmos. Chem. Phys., 7, 4887-4903, doi:10.5194/acp-7-4887-2007, 2007.

Plane, J. M. C.: Cosmic dust in the earth's atmosphere, Chem. Soc. Rev., 41, 6507-6518, doi:10.1039/c2cs35132c, 2012.

Prospero, J. M. and Carlson, T. N.: Radon-222 in North Atlantic Trade Winds, Its Relationship to Dust Transport from Africa, Science, 167, 974-977, doi:10.1126/science.167.3920.974, 1970.

Prospero, J. M. and Carlson, T. N.: Vertical and Areal Distribution of Saharan Dust over Western Equatorial North-Atlantic Ocean, J. Geophys. Res., 77, 5255-5265, doi:10.1029/JC077i027p05255, 1972.

Prospero, J. M. and Nees, R. T.: Dust Concentration in Atmosphere of Equatorial North-Atlantic - Possible Relationship to Sahelian Drought, Science, 196, 1196-1198, doi:10.1126/science.196.4295.1196, 1977. 
Prospero, J. M., Glaccum, R. A., and Nees, R. T.: Atmospheric Transport of Soil Dust from Africa to South America, Nature, 289, 570-572, doi:10.1038/289570a0, 1981.

Prospero, J. M. and Nees, R. T.: Impact of the North African Drought and El-Nino on Mineral Dust in the Barbados Trade Winds, Nature, 320, 735-738, doi:10.1038/320735a0, 1986.

Prospero, J. M. and Lamb, P. J.: African Droughts and Dust Transport to the Caribbean: Climate Change Implications, Science, 302, 1024-1027, doi:10.1126/science.1089915, 2003.

Ratmeyer, V., Balzer, W., Bergametti, G., Chiapello, I., Fischer, G., and Wyputta, U.: Seasonal Impact of Mineral Dust on DeepOcean Particle Flux in the Eastern Subtropical Atlantic Ocean, Mar. Geol., 159, 241-252, doi:10.1016/s0025-3227(98)00197-2, 1999a.

Ratmeyer, V., Fischer, G., and Wefer, G.: Lithogenic Particle Fluxes and Grain Size Distributions in the Deep Ocean off Northwest Africa: Implications for Seasonal Changes of Aeolian Dust Input and Downward Transport, Deep-Sea Res. Pt. I, 46, 1289-1337, doi:10.1016/s0967-0637(99)00008-4, 1999b.

Sarnthein, M., Tetzlaff, G., Koopmann, B., Wolter, K., and Pflaumann, U.: Glacial and Interglacial Wind Regimes over the Eastern Subtropical Atlantic and North-West Africa, Nature, 293, 193-196, doi:10.1038/293193a0, 1981.

Schütz, L.: Long Range Transport of Desert Dust with Special Emphasis on the Sahara, Ann. NY Acad. Sci., 338, 515-532, doi:10.1111/j.1749-6632.1980.tb17144.x, 1980.

Shao, Y. P., Wyrwoll, K. H., Chappell, A., Huang, J. P., Lin, Z. H., McTainsh, G. H., Mikami, M., Tanaka, T. Y., Wang, X. L., and Yoon, S.: Dust Cycle: An Emerging Core Theme in Earth System Science, Aeolian Res., 2, 181-204, doi:10.1016/j.aeolia.2011.02.001, 2011.

Skonieczny, C., Bory, A., Bout-Roumazeilles, V., Abouchami, W., Galer, S. J. G., Crosta, X., Diallo, A., and Ndiaye, T.: A ThreeYear Time Series of Mineral Dust Deposits on the West African Margin: Sedimentological and Geochemical Signatures and Implications for Interpretation of Marine Paleo-Dust Records, Earth Planet. Sc. Lett., 364, 145-156, doi:10.1016/j.epsl.2012.12.039, 2013.

Sokolik, I. N. and Toon, O. B.: Incorporation of Mineralogical Composition into Models of the Radiative Properties of Mineral Aerosol from UV to IR Wavelengths, J. Geophys. Res.-Atmos., 104, 9423-9444, doi:10.1029/1998jd200048, 1999.

Stein, A. F., Draxler, R. R., Rolph, G. D., Stunder, B. J. B., Cohen, M. D., and Ngan, F.: NOAA's HYSPLIT Atmospheric Transport and Dispersion Modeling System, B. Am. Meteorol. Soc., 96, 2059-2077, doi:10.1175/BAMS-D-14-00110.1, 2015.
Stuut, J. B., Zabel, M., Ratmeyer, V., Helmke, P., Schefuss, E., Lavik, G., and Schneider, R.: Provenance of Present-Day Eolian Dust Collected off NW Africa, J. Geophys. Res.-Atmos., 110, D04202, doi:10.1029/2004jd005161, 2005.

Stuut, J. B., Boersen, B., Brück, H. M., Hansen, A., Koster, B., van der Does, M., and Witte, Y.: Cruise Report RV Meteor M89, TRAFFIC I: Transatlantic Fluxes of Saharan Dust, 3-25 October 2012, available at: http://melia.nioz.nl/public/dmg/rpt/crs/ m89.pdf (last access: 20 October 2016), 2012.

Stuut, J. B., Brummer, G. J. A., Van der Does, M., Friese, C., Geerken, E., van der Heide, R., Korte, L., Koster, B., Metcalfe, B., Munday, C. I., van Ooijen, J., Siccha, M., Veldhuizen, R., de Visser, J.-D., Witte, Y., and Wuis, L.: Cruise Report RV Pelagia 64PE378, TRAFFIC II: Transatlantic Fluxes of Saharan Dust, 9 November-6 December 2013, available at: http://melia.nioz.nl/ public/dmg/rpt/crs/64pe378.pdf (last access: 20 October 2016), 2013.

Tsamalis, C., Chédin, A., Pelon, J., and Capelle, V.: The seasonal vertical distribution of the Saharan Air Layer and its modulation by the wind, Atmos. Chem. Phys., 13, 11235-11257, doi:10.5194/acp-13-11235-2013, 2013.

Tsoar, H. and Pye, K.: Dust Transport and the Question of Desert Loess Formation, Sedimentology, 34, 139-153, doi:10.1111/j.1365-3091.1987.tb00566.x, 1987.

van der Does, M., Korte, L. F., Munday, C. I., Brummer, G.J. A, and Stuut, J.-B. W.: Particle size of Saharan dust in the Atlantic Ocean, from October 2012 to November 2013, doi:10.1594/PANGAEA.863030, 2016.

WHO: World Health Organization, Air Quality Guidelines, Global Update 2005, Druckpartner Moser, Germany, 484 pp., 2006.

Wilcox, E. M., Lau, K. M., and Kim, K.-M.: A Northward Shift of the North Atlantic Ocean Intertropical Convergence Zone in Response to Summertime Saharan Dust Outbreaks, Geophys. Res. Lett., 37, L04804, doi:10.1029/2009GL041774, 2010.

Yu, H., Chin, M., Bian, H., Yuan, T., Prospero, J. M., Omar, A. H., Remer, L. A., Winker, D. M., Yang, Y., Zhang, Y., and Zhang, Z.: Quantification of Trans-Atlantic Dust Transport from Seven-Year (2007-2013) Record of CALIPSO Lidar Measurements, Remote Sens. Environ., 159, 232-249, doi:10.1016/j.rse.2014.12.010, 2015.

Zühlsdorff, C., Wien, K., Stuut, J.-B. W., and Henrich, R.: Late Quaternary Sedimentation within a Submarine Channel-Levee System offshore Cap Timiris, Mauritania, Mar. Geol., 240, 217-234, doi:10.1016/j.margeo.2007.02.005, 2007. 